\title{
Justice in Hispanic America: The Case of the Social Uses of Judicial Competence in Chile, 1825-1875
}

\author{
Víctor Mauricio Brangier Peñailillo \\ Bernardo O'Higgins University
}

\begin{abstract}
In the context of the intense litigiousness of the colonial period and the nineteenth century in Hispanic-America, this article problematizes social evaluations of and attitudes towards republican judicial design. It presents original research on the case of a rural area in SouthCentral Chile, during the reorganization of the competences of local judges. We have examined 85 trials for interpersonal conflicts between middle and lower-middle class residents; this data was analyzed for the social uses of competences in the new judicial organization. Drawing on the theoretical approach of 'jurisdictional power,' this study demonstrates the social evolution of a know-how within the judiciary to adapt to its new organizational design, the increasing recourse to professional judges, and the permissiveness of judges towards social transgressions of judicial competence. The article concludes that the validity and tensions within social evaluations of accessibility to justice are part of an inheritance of a long regional political culture.
\end{abstract}

\section{INTRODUCTION}

In recent decades, Latin American historiography has focused on the social uses of justice. These studies have shed light on the deployment of tactics and representations of social sectors in judicial situations, favoring 'traditional' contexts during the colonial period and the nineteenth century. Such research focused on indigenous recourse to judges and how they appropriated Hispanic judicial institutions to defend their prerogatives (Stern 1982; Zetling and Thomas 1992; Galante

Social Evolution \& History, Vol. 19 No. 1, March 2020 113-134

(C) 2020 'Uchitel' Publishing House

DOI: $10.30884 / \mathrm{seh} / 2020.01 .06$ 
2001; Owensby 2011). It has also thus been possible to perceive the litigiousness of Afrodescendant slaves - who knew the rights granted to them by Spanish law, the strategies they used in the courts to obtain welfare quotas, personal manumission (when slave owners freed their slaves) and even the gradual erosion of the slave system (Reis 1986; Aguirre 1993; Landers 2000).

If the judicial system was frequently and intensely used by the indigenous and afro-descendant slaves, logically, other social sectors which would have been less dominated or oppressed - also deserved attention regarding their possible access to justice to obtain benefits. Thus, research has scrutinized judicial archives to identify the attempted and/or interested use of the judiciary by a range of actors located between the middle and lower sectors, both in urban and rural settings. Current literature regarding this last point is extensive (for a review, see Barriera and Polimene 2010).

Due to the data provided by such aforementioned work, several questions thus arise regarding the mutual relationship between the know-how that motivated the litigiousness of the social actors and the judicial institutionalism. This question is of great importance in contexts in which the authorities in Hispanic America designed profound transformations in judicial administration. This is because such changes provoked scholars to question the ways in which society understood these changes in order to adapt their strategies socially in their use of the new judicial framework (Scardaville 2000). This article problematizes the evolution of social uses of justice in the context of the configuration of a new judicial administration scheme in the nineteenth century. Specifically, I address the ways in which residents of a given area understood and managed the changes regarding the distribution of competences among new judges appointed to local areas. Based on a microanalysis of the Central-Southern rural zone of Chile between 1825 and 1875, the article aims to examine residents' adaptations in the social uses of justice, given the new configuration of judges and their judicial competences. In addition, I propose to evaluate the social use of professional judges as a new instance of republican judicial design. This article hypothesizes that local residents understood that the contemporary legislation and the authorities in charge of the judicial organization aimed at more clearly defining and delineating judicial powers. The subjects, who had their own tradition regarding the uses of the judiciary, read the new provision of judges in their territory and went to the most likely judge or before whom they 
could more likely obtain benefits, independent of whether the subjects had to litigate or not in front of that judge. The results of this research verified that these social actors actively transferred their demand from one judge to another, transgressing the competences of each judge. Additionally, the increasing recourse of local actors to professional judges also evidence a social understanding of the judicial competences and a prerogative of professional judges over lay judges.

\section{METHODS}

This study is based on a sample of 85 judicial records processed between 1825 and 1875 in the South-Central zone of Chile and stored in the National Historical Archive of Chile. The criteria for documentary selection were as follows. First, trials were selected for interpersonal conflicts, where cases were opened as criminal complaints and/or accusations of crimes that threatened a party's life, body, property and honor. Such matters of great concern to local residents allow an understanding of the pressures of obtaining a favorable judicial resolution. Second, cases were selected where parties to the conflict took the initiative to change judges, by transferring the case from one judge to another. Third, cases involving residents of the area belonging to middle and lower social strata were privileged. This included small agricultural and livestock owners, small-scale traders, artisans, domestic workers, and temporary rural workers, among others in similar categories. The fourth consideration was that the study should have an equitable number of trials for each of the five decades under study. The purpose was to compare, quantitatively, the evolution of the social uses of local justice and the adaptations of such uses throughout the given period. Consequently, 17 cases were selected for each decade. The survey data is represented in Table 1, entitled 'Destination Judge after the Litigant's Initiated Change of Jurisdiction, South-Central Zone of Chile, 1825-1875.' The registry includes the litigants' preferences for the type of destination judge to which they were sent after their demanded transfers. The four categories of judges established by the Regulation of the Administration of Justice of 1824 (Reglamento de Administración de Justicia de 1824) were taken into account: inspector, sub-delegate, mayor, and professional judge (juez de letras).

The geographical area in which the cases were processed comprised a radius of 46,683 square kilometers extended along a longitudinal valley from Santiago to the south. It has been characterized as a rural region since the eighteenth century due to the predominance 
of a large private wheat estate (hacienda) and the scarcity of semiurban centers. According to contemporaneous statistics, in the $1830 \mathrm{~s}$ there were 353,513 people (Urizar 1835: III) and by 1875 the population had risen to 521,573 (Oficina Central de Estadística 1866: 105). Agricultural historiography in Chile has pointed out that in this sector, large agricultural estates inhibited the development of small and medium-sized peasant economies. Even in the nineteenth century, agricultural and livestock production and marketing revolved around the interests of such large production units. Even small landowners were permanent employees and residents on the larger estates (e.g., as tenants) or as temporary workers (Bengoa 1990: 192; Salazar 2009: 217; Lozoya 2014). This area was chosen as a unit of analysis, firstly because at the time of the study and as corroborated by the trials, a series of interpersonal tensions was fostered by the lower availability of the basic resources of the local economy: land and livestock. Secondly, between 1825 and 1875, the Regulation of the Administration of Justice was in force, which established a new hierarchy of competence for each judge installed in the territory.

The theoretical approach of 'jurisdictional power' was used in the analysis of the documentary sample. This conceptual framework was enabled in the last decades by the critical history of the law, and allows an understanding that the political culture of the Iberian monarchy, in the administration of its American territories, did not differentiate a political exercise from a judicial or legal one. The literature on this subject has established that the primary function of the king was to guard the plural rights and customs of the different political bodies that made up the political community. For this purpose, the king had the power to 'pronounce the right' (iuris-dictio) - or declare and enforce those rights - from where the notion 'jurisdiction' and 'jurisdictional power' originated. This power or capacity was associated with doing justice, that is, giving each one what he deserves according to a preestablished and unequal corporate legal order. The monarch delegated this power to every official who comprised the administrative network of the monarchy. ${ }^{1}$ Thus, in the American domains, a judicial function was added to practically all of the government, military, and municipality posts. According to this logic, the judge-authority had to fulfill the main requirement of knowing well the inhabitants of the territory and the nature of social relations amongst them. Thus, he would be empowered to arrive at the most just decision (to judge according to convenience) according to his discretion (Agüero 2008). A direct con- 
sequence of this model was social accessibility to the judiciary, since the inhabitants of each sector could settle their disputes before any node in the network of recognized authorities. This political and judicial design deployed by the Iberian monarchy in its American domains was linked to a European tradition of the participation of laymen (as judges, officers, and jury) in the judicial process (Dubber and Pihlajamäki 2015: 226-227).

This approach allows us to interpret, firstly, the long-term precursors in the social use of access to justice. Residents' accumulative and collective experience reformulated their know-how in judicial situations, and this was used to evaluate the best way to mobilize their causes within the new scenario of the powers of each judge. Secondly, this theoretical framework facilitates the explanation of the predominantly lay and neighborhood character of the judges who constituted the judicial organization as designed in the country since 1824 , as will be detailed below. Thirdly, it allows for an analysis of the documentary sample, as related to the permissiveness with which judges acceded to the litigants' strategies regarding the changing of judicial competences. Their knowledge of litigants and the tradition of deciding on the basis of social convenience (political basis of the jurisdictional power), would have motivated these judges to receive the lawsuits, despite knowing that they were not legally bound to hear the cases. This article and research employs the concept of judicial competence as is provided in the Regulation of the Administration of Justice of 1824. In other words, this competence is understood in terms of the authority of each judge to hear cases in civil or criminal cases, the financial amount (cuantía) (the translation into money or financial terms of the object in dispute), the gravity of the crime, and the territorial radius of each judge. In this sense, the concept fits the definition given by the contemporaneous Spanish jurist Joaquín Escriche (1838: 116), for whom judicial competence refers to the 'right of a judge or tribunal to hear a case.' In this context, this study focused on the attitudes of litigants in their examination of different rights of each judge, in their search for the one most relevant to their needs.

\section{THE SEARCH FOR THE BEST JUDGE}

In Chile, the administrative division of the territory that was planned in the republican period followed the French revolutionary model of 'departments' (Sanhueza 2008). The Constitution as promulgated in 1822 reformulated the whole division into six departments. Each of 
these grids had to be divided into delegations and then into districts. The Charter of the following year respected this initiative by dividing the territory into departments, and the departments into delegations, which were subsequently divided into sub-delegations. Additionally, the Charter proposed the subdivision of these sub-delegations into prefectures and finally into inspections (Somoza 1935: 48-49). Subdelegations and inspections were organized by a successive numerical order within each department. Moreover, this system replaced the old local councils (cabildos) with municipalities (Carrasco 2002: 81). This was the design on which the first republican regulations for the organization and attribution of judges were planned: the Regulation of the Administration of Justice of 1824. Thus, the officials in charge of those units were also put to judicial uses, in which mayors, subdelegates, and inspectors were officiated as lay judges and residents in each locality.

The Regulation specified the competence of each judge. In lowprofile civil matters and criminal injury or light faults, the complaint had to appear before the inspector of the defendant's community. In this situation, the parties could appeal to the superior sub-delegate to that judge. In addition, if the inspector was involved, he would be replaced by the next judge according to the numerical order as explained above, the same mechanism that should operate for the sub-delegated judges. For matters of greater importance in civil matters and for serious crimes in criminal jurisdiction, the professional judges should hear the cases. If professional judges did not exist, he would be replaced by the mayor of the main city of the department where the crime took place (Anguita 1913: 152-154).

The judicial competences that were outlined in the Regulation were only altered by changes in the boundaries of districts and subdelegations and the progressive subdivisions that these units experienced. ${ }^{2}$ But in general, the scheme remained unchanged during the time of study until the enactment of the Code of the Organization and Attribution of Tribunals of 1875. Since then it was established that in the old districts, a 'district judge' would operate with the inspectors, separating the judicial, governmental and police functions that these officials had hitherto been focused on. The same separation was established for the case of the sub-delegations and the 'sub-delegate judges' (Estado de Chile 1875: 16)

The appointment of professional judges to local courts was also based on the administrative division of the territory. In the 1820 s, the 
area was composed of two Provinces, Colchagua by the north and El Maule by the south. Both were established in 1826 (Sanhueza 2008: 487). Since then there was a professional judge in each of these Provinces. There were only two judges for the whole zone, both residing respectively in the main cities of each province: San Fernando and Cauquenes. Over the decades, the provinces were progressively subdivided, and towards the end of the period under study, the area was composed of five provinces. Based on their location from north to south, these provinces were: Colchagua, Curicó, Talca, Linares and Maule. Within this radius, ten professional judges were appointed in these main cities (Somoza 1935).

Data evidenced that the litigants knew the different levels of the judicial network designed for the territory of their residence. From the understanding of the spheres of judicial competences, men and women involved in interpersonal conflicts made use of every rung of the judicial organization. Of course, the degree of success of their efforts depended in each case on the attitude of the judges to validate the stratagem and experience of the litigant. Occasionally, the plaintiffs took advantage of the lack of communication between the different judges. In this way, they could leave an unfinished trial and re-open it before another judge (to verify, see e.g., Archivo Nacional Histórico de Chile 1835a, 1840a, 1862). There were also complaints taken before two judges simultaneously (Ibid.). The lack of precision in the territorial delimitation of the administrative units favored the attitude of the litigants in their exploration of the proclivity of each judge. The following examination of a case from the sample enables us to picture the phenomenon as just described.

In September 1840, Jose Orrego, a resident of the Codegua subdelegation (department of Rancagua, province of Colchagua), appeared before the mayor of the city of Santa Cruz, Pedro Melo. Orrego, through a representative, filed a case against his local subdelegate, Francisco de Borjas, for having ordered him to leave his home within a three-day deadline. Before that final day arrived, Orrego sent his wife to find out from the same sub-delegate the reason behind the order. He was thus informed that he had been banished for being 'one who provides shelter to thieves' (un aposentador de ladrones). In Orrego's opinion, Judge De Borjas's sentence was gratuitous since he had validated 'sinister reports' (informes siniestros) from Orrego's local adversaries. Furthermore, Orrego accused the judge of acting unjustly, condemning him for 'not conducting a trial by law, 
which expressly and ultimately prohibits Article 133 of the Constitution.' The litigant added that if 'public opinion accuses me of crime, in good time the case will be made ...' (la opinión pública me acusa de criminal, en hora buena fórmese la respectiva causa...) (Archivo Nacional Histórico de Chile 1840b: 1).

The plaintiff had moved 125 kilometers from his residence to present this case to the mayor of Santa Cruz. However, it is clear that only 17 kilometers south of his native town, there was a sub-delegate's judicial competence that corresponded to Orrego's residential address. Additionally, Orrego's case also corresponded to the competence of the mayor of the city of Rancagua (nearer his place of residence than Santa Cruz). In the entire file regarding this case, there was no evidence to explain the reasons for its transfer to such a distant judge. However, Jose Orrego seemed prepared to achieve his objective. The complaint culminated in a double request to the mayor Melo. On the one hand, for Melo to suspend the order of the subdelegate, and on the other, that if there were any other accusations against Orrego, he should be granted an immediate transfer to Melo (Archivo Nacional Histórico de Chile 1840b: 1).

Although the complaint transgressed the radius of judicial competences provided by the Regulation of 1824, Mayor Melo immediately agreed to one of Orrego's requests: the suspension of the sentence as decreed by the sub-delegate. The second petition, however, underwent a slight modification. It was not possible to guarantee that knowledge of the accusation of Orrego as 'one who provides shelter to thieves' as received by Judge Borjas - would reach the mayor. Nevertheless, he ordered the sub-delegate to inform him about 'the information that gave rise to the said order' (Archivo Nacional Histórico de Chile 1840b: 2). The judge's report arrived nine days later. It contained the order of suspension of the previous ruling, the clarification of having decided against Orrego based on the following sources: information that he was a 'bad man from several honorable people' (hombre malo por varias personas honradas), the statements of eight witnesses who corroborated the bad reputation of the accused, his role in organizing the livestock theft, and his actions as 'one who provides shelter to thieves.' The trial was unfinished. The file ended at the testimony of the last witness, who, like the rest of the informants, referred to Orrego as 'a bad man, [as] he has heard ...' (que es hombre malo, ha oido decir...) (Ibid.: 1). 
It is not possible to deduce if the mayor Melo took into consideration these new testimonies to return the case to the sub-delegate of Codegua, to adjudicate against Orrego, or to transfer the case to the professional judge. In any case, this example provides clues to analyse how a resident of a local area, who suffered prejudice due to a bad reputation drummed up by his rivals, decided to have his case before a different, distant judge located more than 100 kilometers from the actual mayor that corresponds to his residence, one who is nevertheless surely unaware of the bad reputation associated with his name.

\section{AN EXAMINATION OF PROFESSIONAL JUDGES (JUECES DE LETRAS)}

The contrast between the regulations establishing the delimitation of judicial competences and the individual search for the most suitable judge by litigants was evident in the increasing recurrence to professional judges. Although this type of judges constituted the minority in the area, the parties in conflict clearly understood the greater decision-making capacity that they possessed over the other lay judges. Indeed, in view of the impossibility of appointing more professional judges in this area, due to the refusal of the same lawyers to move to remote territories (De Ramón 1989), successive governments decided to implement periodic judicial inspections to formalize the procedures enabling lay judges to prosecute. This was dictated by the Regulation of 1824 and can be found in the reports of visits available in the archives of the Ministry of Justice in the National Historical Archive of Chile. Moreover, in September 1838, a law was passed to extend the jurisdiction of the professional judges over mayors, stipulating that they could take charge of cases processed by mayors regardless of whatever state they were in (Anguita 1913: 312-313).

Table 1 demonstrates a preliminary approximation of litigants' preferences for bypassing the judicial competences as established by the law, and the transference of their demands to the professional judges. The table is a synthesis of the judicial options in the plaintiffs' strategies and the evolution of their preferences over time. 
Destination Judge after the Litigant's Initiated Change of Jurisdiction, South-Central Zone of Chile, 1825-1875

\begin{tabular}{|l|c|c|c|c|c|c|}
\hline \multicolumn{1}{|c|}{ Judge } & $\begin{array}{c}\mathbf{1 8 2 5 -} \\
\mathbf{1 8 3 5}\end{array}$ & $\begin{array}{c}\mathbf{1 8 3 6}- \\
\mathbf{1 8 4 5}\end{array}$ & $\begin{array}{c}\mathbf{1 8 4 6 -} \\
\mathbf{1 8 5 5}\end{array}$ & $\begin{array}{c}\mathbf{1 8 5 6}- \\
\mathbf{1 8 6 5}\end{array}$ & $\begin{array}{c}\mathbf{1 8 6 6}- \\
\mathbf{1 8 7 5}\end{array}$ & Total \\
\hline Inspector & 2 & 3 & 1 & 1 & 3 & 10 \\
\hline Sub-delegate & 7 & 2 & 4 & 2 & 0 & 15 \\
\hline Mayor & 5 & 7 & 3 & 1 & 3 & 19 \\
\hline $\begin{array}{l}\text { Professional } \\
\text { judges }\end{array}$ & 3 & 5 & 9 & 13 & 11 & 41 \\
\hline Total & 17 & 17 & 17 & 17 & 17 & $\mathbf{8 5}$ \\
\hline
\end{tabular}

Source: Based on 85 criminal cases due to interpersonal conflicts, as found in the National Historical Archive of Chile.

Table 1 shows that, in the documentary sample accessed for this research, the litigants preferentially chose professional judges in transferring their legal cases. Of the four categories of judges in existence since the mid-1820s, an assessment of filed criminal cases showed that, in the majority of cases, the plaintiffs ultimately turned to a professional judge. This category comprised 41 of the 85 trials, equivalent to 48.2 per cent. Following this, and with a comparable difference in frequency, 19 re-trials (22.3 per cent) in total took place in front of the mayor. The third and fourth popular options were the transferal of cases to sub-delegates and inspectors, with 15 (17.6 per cent) and 10 (11.7 per cent) cases respectively.

A diachronic analysis of Table 1 shows that preference for professional judges was a progressive phenomenon throughout the five decades of study. Of the 17 files reviewed for the first decade, the litigants chose to change their claim to a professional judge in only three instances. During this period, the subjects chose as the final hearer of their legal cases, sub-delegates (on seven occasions) and then, mayors (in five cases). In the second decade, professional judges were privileged in five cases, while transfers of cases to mayors became the most popular option with seven cases. Already in the third decade, the transfer of cases to a professional judge became the most popular option, with nine adjudications in this category. During this period, transfers to the other types of judges occurred with less frequency, with eight cases in total across the three remaining categories. In the fourth decade, the concentration of cases transferred to professional judges became more acute, with 13 recorded migration of trials, while 
the rest of the judges only received four transferred cases in total. The last decade continued with this trend. The litigants chose to move their cases to professional judges on 11 occasions, to the mayors and inspectors in three occasions respectively, with no record of transfers to sub-delegates. For the purposes of plotting this evolution and to conduct a qualitative analysis of the phenomenon, two specific cases were examined in which the litigants appealed to the professional judges, thereby transgressing the jurisdiction of lay judges.

The youth Gregorio Bustamante was in a 'shop house' (casa de venta) in the town of Roma, six kilometers east of San Fernando, the capital of the province of Colchagua. It was eight o'clock on the night of November 14, 1830. Cayetano Maturana, the mayor of the neighboring town of Talcarehue was also present. Meeting with Bustamante, the mayor 'approached him unexpectedly with a machete he had been hiding, and hit him in the left arm with the weapon, and stabbed him in the right arm, in the presence of several individuals who were there, and these wounds left him close to dying' (se dirigió a él de un modo improviso con un machete que llevaba oculto, y dio un machetazo en el brazo izquierdo y en el derecho un puntazo, a presencia de varios individuos que alli habian, que de estas heridas estaba próximo a morir) (Archivo Nacional Histórico de Chile 1830: 1). The file on this case did not make clear the reasons for the assault, if there had been provocation on the part of the victim, or if there was a pre-existing conflict that could explain the actions of Maturana. What is striking here is that the mayor of Roma was among the 'several individuals' who witnessed the event. Later, according to the witness Juan Briones, one of the brothers who owned the shop house or scene of the incident, the mayor of Roma would have restrained Maturana from continuing the aggressions. Due to the profound wounds, the conflict had to be treated as a criminal case within the competence of this very same mayor of Roma. However, the case file began with a lawsuit filed by the victim's father, Francisco Bustamante, before Pedro Arriagada, the professional judge in the province of Colchagua.

In the case described, the father of the attacked youth bypassed the competence of the mayor of Roma and traveled six kilometers to the city of San Fernando to open the case for prosecution before the professional judge. ${ }^{3}$ This trip was made the day after the attack, as the complaint was dated November 15, 1830. Judge Arriagada ordered the governor of the department to send him the witnesses of the incident. Ten days later, 
José Briones, the owner of the shop house where the crime occurred, made his declaration, and 25 days after this, his brother also testified, as indicated above. Both confirmed to have witnessed the aggression of the accused against the young Bustamante. Although the judicial file did not continue after this point, as far as it is possible to infer, Francisco Bustamante's strategy of appealing to the highest judicial authority in the province would have allowed him to obtain incriminating testimony against the aggressor.

The second case took place on July 28, 1875. Manuel Burgos was a judicial representative and resident of the city of Linares, at the southern end of the area under study and in the province of Linares. Burgos asked the professional judge Antonio Vidal to hear his complaint 'for the crooked administration of justice' (por torcida administración de justicia) that stood against Cesareo Orrego. The accused was as a sub-delegate of the locality of Pilcoyán of that province (Archivo Nacional Histórico de Chile 1875: 1).

Manuel Burgos was representing Pedro Castro, who was involved in an incident regarding debt with the siblings of Burgos himself. The lawsuit appeared to be the judicial manifestation of a family dispute. According to the representative, Gabriel Burgos had died without having paid 45 pesos that was owed to his sister Dolores Burgos. The debt had a bail that fell onto Pedro Castro, who rejected assuming that role because he claimed at the time not to recognize his signature as a guarantor since he did not know how to sign. Consequently, Dolores sued against Matías Sepulveda, the sub-delegate of her residence in Pilcoyán. According to a request for a complaint filed by Manuel Burgos, Judge Sepúlveda was not satisfied with Pedro Castro's explanation. Although the sub-delegate Sepulveda left the issue in this state, after a period of time, the judge, 'obeying strange propositions' (obedeciendo a sugestiones extrañas), issued an order of arrest and imprisonment against Pedro Castro. Before a 'proceeding so unusual' (proceder tan inusitado), the affected party decided to look for a judge to whom he could appeal: there was no other remedy besides appealing such a procedure. [After being] granted the appeal, it was not known to which sub-delegate they should submit their appeal, due to how the division of the department of San Javier, Pilocoyan, at that time, remained as the last section; so it was necessary to file an appeal to the sub-delegate No. 1 of the town (Archivo Nacional Histórico de Chile 1875: 2). 
The administrative reform necessarily had repercussions on the change of judicial powers. As the complainant stated, the sub-delegation of Pilcoyán remained in the last section of the territorial area, so it was his responsibility to transfer the appeal to the sub-delegation classified as number one. Pedro Castro and his representative took advantage of the recent administrative division to gain access to a subdelegate other than that of their residence, whose ruling had been absolutely adverse. This new local judge ordered a declaration. Dolores Burgos, as advised by a lawyer, rejected the competence of the new sub-delegate and demanded that the case be transferred to a third subdelegate. Pedro Castro protested, insisting that the judge of the first sub-delegation should hear the case.

This particular case file is interesting because the dispute focused on the competence of one judge over another. Meanwhile, Matías Sepúlveda (the first judge who opened the case) was replaced by Cesáreo Orrego, the fourth sub-delegate who entered the conflict. It was finally this judge against whom the Castro representative presented the initial complaint before the professional judge of Linares. According to the indictment, when Orrego learned of the pending trial between Castro and Dolores Burgos, he did not know the state of appeal that the case was in and renewed the above-mentioned arrest warrant and embargo (Archivo Nacional Histórico Histórico de Chile 1875: 3).

The judge Antonio Vidal seemed to understand the core of the family conflict and the tactics of the parties regarding the network of available judicial competences. Thus, he asked the sub-delegate Cesáreo Orrego to report on the matter. Orrego replied the following week. The relevant document provides data of interest to elucidate the social uses of judicial competences. Judge Orrego confirmed that his predecessor had heard Dolores Burgos's complaint against Castro, but added that the case had not been in favor of Castro, who had been proven to have signed as guarantor of the debt at issue. He pointed out that the affected party was granted six days to appeal the sentence, but there was a request to do so after the deadline, before the second subdelegate, which made it unlawful to revert to the first sub-delegate of the department (Ibid.: 5). Castro and his representative were prepared to take the case away from the initial sub-delegate, regardless of the processes prescribed by the regulations and which the presiding judge had intended to enforce. In the end, the case remained inconclusive. Nevertheless, the source evidenced traces of hasty attempts to transfer 
the case from one judge to another. The movement had to be made with determination, as soon as the judge was inclined to one side of the conflict. This motivation led Pedro Castro to the professional judge of Linares to charge the original judge, whose judicial competence he had intended to detach himself from since the beginning.

\section{DISCUSSION: 'JURISDICTIONAL POWER' AND THE SOCIAL USES OF JUDICIAL POWERS}

The archival evidence allows us to address the research objective, which is to illuminate the social attitudes towards the changes in the design of judicial competence in local areas. The judicial files open a window to address the first objective of the study: to examine the social uses of the judicial competences of each type of judge, according to the Regulation of the Administration of Justice of 1824, and the progressive adaptations undertaken by the residents of the SouthCentral zone of Chile to better mobilize their interests under the new scenario. Simultaneously, the examination of the documentary sample led to the second objective: to evaluate the recurrence of the litigants to the professional judges, as emerging nuclei of judicial authority.

The three case studies show residents of the area privileging the opportunity of access to a judge inclined to support their position, over respect for the design of the judicial competences of each judge starting from 1824. These three situations revealed the development of a know-how that enabled the social actors to navigate the complex judicial network in their area and evaluate to which judge they should ideally transfer their cases. In the first case, the resident of the town of Codegua, Jose Orrego, transgressed the order of judicial competences to avoid filing his claim before the sub-delegation of his territory or the next mayor. Instead, he moved 125 kilometers to the south in search for the judge of the mayor of the city of Santa Cruz. The bad reputation with which his name was associated in his resident locality motivated him to look for a judge who did not know of those rumours, a lack of knowledge which could consequently impact the case in his favor. The case is representative of an attitude demonstrated by the litigants in the rest of the documentary sample, who instrumentalized the permissiveness with which lay judges and neighbors responded to these changes in judicial competences.

The data in Table 1 favor an analysis of the change within a longstanding structure of social uses of judicial competences. The appearance of the professional judges as new territorial agents and with 
increasing powers over the rest of the lay judges, made social actors at the time progressively identify in them a greater probability in obtaining a favorable outcome. The two case studies that were presented later (representative of the actions and attitudes of the majority in the sample) illustrated a social interpretation of how the new design of judicial competences enabled new opportunities for local residents.

The theoretical approach of 'jurisdictional power' allows for an interpretation of the evidence presented in terms of an emergence within a long-term process that was already taking place in Hispanic America during the colonial period. The political culture of the Iberian monarchy had adapted to the management of a political community composed of bodies which had their own juridical organization. Politics was based on the doing of justice, for the king and his agents had to protect those heterogeneous rights that governed cabildos, religious orders, secular clergy, militias, universities, unions, guilds, castes, etc. (Lempérière 2005; Garriga 2006; Mazin 2007). The management of politics meant enabling the access to justice to society to hear litigants' cases and to take the most appropriate action. In this way, everyone would be granted what he deserved according to that plural legal system and according to the fragile social equilibrium of each locality.

The validity of this political structure in the American colonies of Spain produced an intense and extensive social litigiousness, as discussed in the above review of the relevant literature. Such social experiences generated a know-how that included the practices of speaking, listening, and acting correctly in a judicial situation (Brangier and Barriera 2015; Brangier 2019), as well as the search for the most appropriate judge. The analyses that this article has focused on must be understood within this broader context and a critical historical juncture in which a specific hierarchization of judicial competences (types of judges) was established. The dynamics of the trials in the sample revealed that inspectors, sub-delegates, and mayors, generally, permitted social actors' search for appropriate judges and tended to omit any reference to the legal pertinence of their search. After all, these judges were also residents of the locale and understood the cultural horizons of litigants, legitimizing social expectations regarding the full accessibility to justice. This intimacy between lay judges and litigants, as the basis of the jurisdictional power, allows an explanation for judges' permissibility regarding the social uses of judicial competences, both in Chile and in Hispanic America. ${ }^{4}$ 
The appearance of the professional judges in this new organization of judicial competences meant an opportunity for the litigants to reformulate the terms of that long-established collective know-how and to re-evaluate the social uses of each judge. The seriousness of the conflicts that were being adjudicated seemed to prevail over the costs of making long journeys to the few cities that had a professional judge. It also seemed to motivate the investment of resources in hiring a judicial representative who would advise the best way to present a case before these magistrates. While those in charge of judicial design in the new Republic were confident that the progressive appointment of professional judges would outweigh the flexibility with which lay judges administered justice, documentary evidence shows that young professional judges who arrived to local areas were willing to receive the litigants even when the claim transgressed the competences of the lay judges. ${ }^{5}$ This scenario enables us to understand the increasing preference of the litigants for professional judges, as reported in Table 1. This is also evident in attitudes such as those of Antonio Vidal, a professional judge in the city of Linares, according to the third case study. The judge acceded to the complaint of the litigant Pedro Castro against the local sub-delegate Cesáreo Orrego, notwithstanding the evident transgression of judicial competences of four subdelegates involved in the processing of the lawsuit. The theoretical apparatus of jurisdictional power allows reading these practices and representations as members of a culture within a longer temporal period, including judges and litigants, who valued accessibility to justice and the permission of social uses of judicial competences.

\section{CONCLUSIONS}

The specific study of the adaptations of the social uses of new judicial competences in Chile in the nineteenth century sheds light on the strategic inclusion of different social sectors in the sphere of a formal institutionalism in permanent construction. ${ }^{6}$ The social uses analyzed were inherited from a litigation practice that had long been practiced. These practices were grounded in the colonial period and facilitated by the Iberian monarchy's political culture - in which politics and justice were intricately interlinked - enabled the social accessibility to this latter order of things. The evidence provided in this article regarding the adaptations that were made based on the know-how in their appearances before professional judges, leads to a series of questions about other changes in the social uses of justice in Hispanic 
America in the long term. How did the different sectors of the population adapt to the development of legalism within the judicial sphere of the region, from the codifications of the mid-nineteenth century (Mirow 2004)? What role did lawyers, representatives, and other mediators play between justice and litigants in these new legal scenarios? At the local level, what were the mutual forms of influence between the old social uses of justice and the newly procedural practices as maintained by (written) national laws?

The study of this mutual influence between society and judicial institutions in Hispanic America must be complemented by microhistorical investigations of the profiles of litigants and their insertion into social networks in terms of the parental, domestic, economic, commercial, legal, etc. The questions related to the subjects involved in the trials and the nature of their relationships will allow a deeper understanding of the roots of conflicts and the reasons for bringing them to justice rather than solving them via social means. Along the same lines, it will open research to the insertion or not of the judges in these social networks to explain their permissiveness and prohibitions before the social uses of their judicial competences. These are research questions that contribute to considering the administration of justice as a 'social phenomenon' (Herzog 1995).

\section{NOTES}

${ }^{1}$ This has been pointed out by critical historians of law, such as Antonio Manuel Hespanha, Bartolomé Clavero, Carlos Garriga, Pablo Fernández Albadalejo, Javier Gil Pujol, and Luis María Díez-Picazo. I refer to the synthesis offered by the historian Miriam Moriconi (2011: 32-40).

${ }^{2}$ In 1859, 459 sub-delegates and 2084 inspectors operated at the national level. In 1871, the number rose to 595 sub-delegations and 2,507 inspectors (Bilot 2013).

${ }^{3}$ For some cases from the data sample where the parties bypassed the judicial competences of mayors of their residence in favour of professional judges, see Archivo Nacional Histórico de Chile 1835b, 1845, 1850.

${ }^{4}$ Darío Barriera (2012) reflected on intimate justice (justicia de proximidad), derived from the 'local and localized' knowledge available to the judges of the Ancient Regime regarding their neighbors.

${ }^{5}$ According to the research of Armando de Ramón (1989: 43-45), the professional judges of this era tended to be on average between 26 to 31 years old.

${ }^{6}$ The analytic camp within regional historiography provoked the work of Florencia Mallon (2003) regarding the role played by the interests of peasant populations and subalterns in the structuring of the Mexican and Peruvian state in the nineteenth century. 


\section{REFERENCES}

Agüero, A. 2008. Castigar y perdonar cuando conviene a la república. La justicia penal de Córdoba del Tucumán, siglos XVII y XVIII. Madrid: Centro de Estudios Políticos y Constitucionales.

Aguirre, C. 1993. Agentes de su propia libertad. Los esclavos de Lima y la desintegración de la esclavitud, 1821-1854. Lima: Pontificia Universidad Católica del Perú.

Anguita, R. 1913. Leyes promulgadas en Chile desde 1810 hasta el 1 de junio de 1913. Tomo I. Santiago: Barcelona.

Archivo Nacional Histórico de Chile [National Historical Archive of Chile]. 1830. Juzgado del crimen de San Fernando. Criminal contra D. Cayetano Maturana, por las heridas perpetradas en D. Gregorio Bustamante.

Archivo Nacional Histórico de Chile [National Historical Archive of Chile]. 1835a. Juzgado del crimen de Rancagua. Contra Moreno, Juan i otro. Tropelías.

Archivo Nacional Histórico de Chile [National Historical Archive of Chile]. 1835b. Juzgado del crimen de Linares. Causa criminal seguida contra el reo Gregorio Sierra por unas heridas mortales que dio a Miguel Quintana. Legajo 1.

Archivo Nacional Histórico de Chile [National Historical Archive of Chile]. 1840a. Against Francisco Parraguez. For Hitting. Legajo 30. Original in Spanish (Juzgado del crimen de Rancagua. Contra Francisco Parraguez. Por golpes. Legajo 30).

Archivo Nacional Histórico de Chile [National Historical Archive of Chile]. 1840b. Against Orrego, José María. Robbery. Legajo 30. Original in Spanish (Juzgado del crimen de Rancagua. Contra Orrego, José María. Robo. Legajo 30).

Archivo Nacional Histórico de Chile [National Historical Archive of Chile]. 1845. Criminal Case against Luis Arriagada for Animal Theft. Legajo 15. Original in Spanish (Juzgado de Quirihue. Criminal contra Luis Arriagada por robo de animales. Legajo 15).

Archivo Nacional Histórico de Chile [National Historical Archive of Chile]. 1850. Criminal Case Pursued by Juan José Pergue against Don José Domingo Troncoso Regarding Injuries. Legajo 171. Original in Spanish (Juzgado del crimen de Cauquenes. Espediente criminal seguido por Juan José Pergue contra Don José Domingo Troncoso sobre injurias. Legajo 171).

Archivo Nacional Histórico de Chile [National Historical Archive of Chile]. 1862. Injuries. Raimundo Jais and José Ignacio Tatin. Legajo 817. Original in Spanish (Juzgado del crimen de Talca. Injurias. Raimundo Jais con José Ignacio Tatin. Legajo 817). 
Archivo Nacional Histórico de Chile [National Historical Archive of Chile]. 1875. Juzgado del crimen de Linares. Criminal por torcida administración de justicia. Querellante. - Don Pedro Castro; Querellado. - Don Cesáreo Orrego, Subdelegado. Legajo 10. Original in Spanish (Criminal Case for the Crooked Administration of Justice. - Don Pedro Castro; Complainant. - Don Cesareo Orrego, Sub-delegate. Legajo 10).

Bengoa, J. 1990. Social History of Chilean Agriculture. Vol. 2. Haciendas and Peasants. Santiago: CHR - Colection of Historical Research. Original in Spanish (Bengoa, J. Historia Social de la Agricultura Chilena. Tomo II. Haciendas y Campesinos. Santiago: SUR - Colecciones Estudios Históricos).

Barriera, D. and Polimene, P. 2010. Justices and Societies. Alleyways Traced from History. In Barriera, D. (ed.), Justice and Forms of Authority. Political Organization and Local Justice in Border Territories. El rio de la Plata, Córdoba, Cuyo y Tucumán, $18^{\text {th }}$ and $19^{\text {th }}$ Century (pp. 9-15). Rosario: ISHIR CONICET-Red Columnaria. Original in Spanish (Barriera, D. y Polimene, P. Justicias y sociedades. Bocacalles trazadas desde la historia. In Barriera, D. (ed.), La justicia y las formas de autoridad. Organización política y justicias locales en territorios de frontera. El río de la Plata, Córdoba, Cuyo y Tucumán, siglos XVIII y XIX (9-15). Rosario: ISHIR CONICET-Red Columnaria).

Barriera, D. 2012. Intimate Justice: Past and Present, Between History and Law. PolHis 10: 50-57. Original in Spanish (Barriera, D. Justicia de proximidad: pasado y presente, entre la historia y el derecho. PolHis 10: 50-57).

Bilot, P. 2013. Constructing a Scheme of the Administration of Justice: Sources, Methods, and Results. History and Justice 1: 1-27. Original in Spanish (Bilot, P. Construyendo un esquema de la administración de justicia: fuentes, método y resultados. Chile, siglo XIX. Revista Historia y Justicia 1: 1-27).

Brangier, V. and Barriera, D. 2015. Common Languages in 'the Justices of Judges.' Historiographic Treatments and Judicial Grounds in Chile and Argentina. Humanidades 32: 227-258. Original in Spanish (Brangier, V. y Barriera, D. Lenguajes comunes en 'justicias de jueces'. Tratamientos historiográficos y fondos judiciales en Chile y Argentina. Humanidades 32: 227-258).

Brangier, V. 2019. Know-How and Knowing to Speak in Justice. Legal and Judicial Cultures in the South Central Zone of Chile. 1824-1875. Rosario: Prohistoria. Original in Spanish (Brangier, V. Saber hacer y decir en justicia. Culturas jurídico-judiciales en la zona centro sur de Chile. 1824 1875. Rosario: Prohistoria). 
Carrasco, S. 2002. The Origins and Validity of Chilean Constitutional Texts. Santiago: Editorial Jurídica. Original in Spanish (Carrasco, S. Génesis y vigencia de los textos constitucionales chilenos. Santiago: Editorial Jurídica).

De Ramón, A. 1989. Chilean justice between 1875 and 1924. Cuadernos de Análisis Jurídico 12: 1-59. Original in Spanish (De Ramón, A. La justicia chilena entre 1875 y 1924. Cuadernos de Análisis Jurídico 12: 1-59.

Dubber, M., and Pihlajamäki, H. 2015. Lay Participation in Modern Law: A Comparative Historical Analysis. Comparative Legal History 3 (2): 224-230.

Escriche, J. 1838. Dictionary of Civil, Criminal, Commercial and Forensic Legislation. Valencia: J. Ferrer Press. Original in Spanish (Escriche, J. Diccionario razonado de Legislación civil, penal, comercial y forense. Valencia: Imprenta de J. Ferrer).

Estado de Chile. 1875. Law of Organization and Attributions of the Tribunals. Santiago: Imprenta de la República. Original in Spanish (Estado de Chile. Lei de Organizacion i Atribuciones de los Tribunales. Santiago: Imprenta de la República).

Galante, M. 2001. The Recent Historiography of Justice in Mexico, the $19^{\text {th }}$ century: Perspectives, Themes, and Contributions. Original in Spanish (Galante, M. La historiografía reciente de la justicia en México, siglo XIX: perspectivas, temas y aportes. Revista Complutense de Historia de América 37: 93-115).

Garriga, C. 2006. Regarding the Government of Justice in Indias (the $16^{\text {th }}$ to $17^{\text {th }}$ Centuries). Revista de Historia del Derecho 34: 67-190. Original in Spanish (Garriga, C. Sobre el gobierno de la justicia en Indias (Siglos XVI-XVII). Revista de Historia del Derecho 34: 67-190).

Herzog, T. 1995. The Administration as a Social Phenomenon: Criminal Justice in the City of Quito (1650-1750). Madrid: Centro de Estudios Constitucionales. Original in Spanish (Herzog, T. La administración como un fenómeno social: la justicia penal de la ciudad de Quito (16501750). Madrid: Centro de Estudios Constitucionales).

Landers, J. 2000. Felipe Edimboro sues for manumission, Don Francisco Xavier Sánchez contests. In Richard, B., and Spurling, G. (eds.), Colonial Lives: Documents on Latin American history, 1550-1850 (pp. 249-268). Oxford: Oxford University Press.

Lempérière, A. 2005. The 'Colonial Issue.' Nuevo Mundo Mundos Nuevos. Original in Spanish (Lempérière, A. La 'cuestión colonial.' Nuevo Mundo Mundos Nuevos). URL: https://nuevomundo.revues.org/437.

Lozoya, I. 2014. Delinquents, Bandits, and Montoneros. Social Violence in the Chilean Rural Space (1850-1870). Santiago: LOM. Original in Span- 
ish (Lozoya, I. Delincuentes, bandoleros y montoneros. Violencia social en el espacio rural chileno (1850-1870). Santiago: LOM).

Mallon, F. 2003. Peasants and the Nation. The Construction of Post-Colonial Mexico and Peru. México: CIESAS - El Colegio de San Luis - El Colegio de Michoacán. Original in Spanish (Mallon, F. Campesino y nación. La construcción de México y Perú poscoloniales. México: CIESAS - El Colegio de San Luis - El Colegio de Michoacán).

Mazin, O. 2007. Gestures of the Real Justice: Solicitors and Agents of the New Hispanic Cathedrals in the Court of Madrid. México: Colegio de México, Centro de Estudios Históricos. Original in Spanish (Mazin, O. Gestores de la Real Justicia: procuradores y agentes de las catedrales hispanas nuevas en la Corte de Madrid. México: Colegio de México, Centro de Estudios Históricos).

Mirow, M. 2004. Latin American Law. A History of Private Law and Institutions in Spanish America. Austin: University of Texas Press.

Moriconi, M. 2011. Politics, Piety, and Jurisdiction. Jurisdictional Culture in the Hispanic Monarchy. Liébana in the $16^{\text {th }}$ to $18^{\text {th }}$ Century. Rosario: Prohistoria. Original in Spanish (Moriconi, M. Politica, piedad y jurisdicción. Cultura jurisdiccional en la Monarquía Hispánica. Liébana en los siglos XVI-XVIII. Rosario: Prohistoria).

Oficina Central de Estadística [Central Office of statistics] 1866. General Census in the Republic of Chile. Taken from 19 April 1865. Santiago: Imprenta Nacional. Original in Spanish (Censo Jeneral de la República de Chile. Levantado el 19 de abril de 1865. Santiago: Imprenta Nacional).

Owensby, B. 2011. Pact between the Distant King and Indigenous Subjects. Justice, Legality, and Politics in New Spain, the $17^{\text {th }}$ Century. Historia Mexicana LXI (1): 59-106. Original in Spanish (Owensby, B. Pacto entre rey lejano y súbditos indígenas. Justicia, legalidad y política en Nueva España, siglo XVII. Historia Mexicana LXI (1): 59-106).

Reis, J. 1986. Rebeliao escrava no Brasil: historia do levante dos Males (1835). San Pablo: Brasiliense.

Salazar, G. 2009. Merchants, Entrepreneurs, and Capitalists. Santiago: Sudamericana. Original in Spanish (Salazar, G. Mercaderes, empresarios y capitalistas (Chile, siglo XIX). Santiago: Sudamericana).

Sanhueza, M. 2008. The First Political Administrative División of Chile, 1811-1826. Historia 41 (2): 447-493. Original in Spanish (Sanhueza, M. La primera división político-administrativa de Chile, 1811-1826. Historia 41 (2): 447-493).

Scardaville, M. 2000. (Hapsburg) Law and (Bourbon) Order: State Authority, Popular Unrest, and the Criminal Justice System in Bourbon Mexico City. In Aguirre, C., and Buffington, R. (eds.), Reconstructing Criminality in 
134 Social Evolution \& History / March 2020

Latin America (pp. 1-17). Washington: Delawere, A. Scholary Resources Inc. Imprint.

Somoza, G. 1935. Political Geography of Chile. 1800-1850. (Historical review). Original in Spanish (Somoza, G. Geografía Politica de Chile. 1800-1850. (Reseña histórica). Santiago: Universidad de Chile, Instituto Pedagógico).

Stern, S. 1982. Perús Indian Peoples and the Challenge of Spanish Conquest: Huamanga to 1640. Madison: University of Wisconsin Press.

Urizar, F. 1835. Repertorio chileno. Santiago: Araucana.

Zetling, J., and Thomas, L. 1992. Spanish Justice and the Indian Cacique: Disjunctive Political Systems in Sixteenth-Century Tehuantepec. Ethnohistory 39 (3): 285-315. 